\title{
PENGETAHUAN, SIKAP DAN TINDAKAN DOSEN DAN MAHASISWA KPI TERHADAP DISINFORMASI DI MEDIA MASSA
}

\author{
Fita Fathurokhmah, M.Si \\ (Dosen Ilmu Komunikasi UIN Syarif Hidayatullah Jakarta) \\ Email: fita.fathurokhmah@uinjkt.ac.id
}

Hoax dan Fakes News termasuk disinformasi. Sebagian dosen memahami disinformasi dan sebagian kurang memahami disinformasi di Media Massa. Bagaimana menghadapi krisis ini? Apalagi sebagian mahasiswa KPI kurang tahu dan kurang bisa membedakan antara informasi bohong, Hoax, berita palsu atau Fake News dan disinformasi. Dosen dan mahasiswa sebagai pembaca virtual sebaiknya bisa membedakan Fake News dan Hoax dan mengetahui penyebaran jauh lebih cepat daripada berita yang akurat dan cover both sides.

Pertanyaan penelitian; 1) Bagaimana dosen KPI dan mahasiswa KPI FIDIKOM UIN Jakarta memahami, menyikapi, dan menghadapi Disinformasi sebagai pembaca media massa?

Penelitian ini menggunakan pendekatan kualitatif. Paradigma konstruktivisme mendalami pemahaman, sikap, dan tindakan pembaca media massa ketika mereka menemui berita bohong, palsu, dan fakes news. Subjek penelitian adalah tiga dosen dan tiga mahasiswa KPI dengan metode FGD dan wawancara mendalam.

Hasil penelitian menunjukkan bahwa pemahaman satu dosen dan satu mahasiswa yang pernah mengikuti workshop tentang disinformasi lebih bisa memahami istilahnya, menyikapi dengan tenang, dan menghadapinya lebih profesional. Sedangkan satu dosen dan satu mahasiswa mencari tahu sendiri, mereka agak ragu dan bingung antara hoax, berita palsu, dan fake news. Sedangkan satu dosen dan satu mahasiswa kurang pengetahuan, tidak menyikapi atau kurang peduli terhadap tersebut dan mereka tidak mencari tahu, apalagi menyikapi, dan menghadapi disinformasi tersebut. Mereka hanya membaca komentar orang lain saja tanpa komentar karena mereka tidak tahu. Jadi mereka tidak tahu dan berupaya untuk tidak komentar. Namun mereka tahu dan mereka akan memberikan fakta baru.

Kontribusi penelitian ini memperkaya dakwah bil hal bagi yang sudah memahami disinformasi, tidak membiarkan orang lain yang sedang ragu dan bingung. Dakwah bil qalam bagi yang tahu. Metode Dakwah bil hikmah menganjurkan diam bila kita tidak tahu permasalahannya dan tidak memiliki fakta.

Keywords: Dakwah bil Hal, Disinformasi, Pengetahuan, Sikap, Tindakan dosen dan mahasiswa

\section{PENGANTAR}

Konsep Hoax dan Fake News di Media massa, Teori pluralis liberal; profesionalisme wartawan mengungkap kebenaran peristiwa. Wartawan menggunakan ruang publik untuk 
mencapai demokrasi (Davis, 2019). Teori Ekonomi Politik Kritis “propaganda media” Herman, Chomsky, 2002); praktik manipulasi berita, membuat berita palsu rekayasa opini publik dipengaruhi kepentingan ekonomi politik kritis; ownership, funding, sourcing, flak, anticommunism.

Media online sekarang mengalahkan media tradisional, masyarakat lebih tertarik pada media online. Kebenaran dalam berita sekarang relatif, sesuai dengan kebenaran pesanan politik dan penguasa. Esensi sebuah berita adalah mengungkapkan kebenaran yang konkrit. Namun seringkali esensi itu disalahgunakan untuk visi dan misi tertentu oleh pihak media. Demi kepentingan ekonomi, politik dan pasar. Padahal sebenarnya masyarakat dapat menggunakan media untuk menyetujui atau menolak kebijakan pemerintah. Media dituntut untuk bisa bersikap pluralis liberal tetapi dihadapkan kenyataan ideologi media pasar, kekuasaan, politik ekonomi. Pendekatan untuk menghadapi Hoax dapat dilakukan dengan "Fast Check" atau "Kontra Narasi" lebih diutamakan daripada memblokir. Pemblokiran dapat dilakukan sebagai langkah terakhir. Sebelum melakukan pemblokiran dapat dilakukan verifikasi media massa.

Kondisi masyarakat Indonesia di era globalisasi ini mengalami banyak perubahan dalam kehidupan masyarakat secara sosial, budaya, ekonomi, politik dan agama. Globalisasi dimaknai sebagai suatu proses yang mendunia dimana individu manusia tidak terikat oleh negara atau batas-batas wilayah. Setiap individu manusia dapat terhubung dengan siapa saja yang ada dibelahan bumi dan terjadi penyebaran informasi dan komunikasi melalui media cetak, elektronik dan media online yang mendunia. Masyarakat Indonesia menghadapi era globalisasi dengan adanya kemajuan dan perkembangan teknologi komunikasi, informasi dan transportasi. Maka dari itu, Globalisasi telah mengubah perilaku kehidupan masyarakat, baik di bidang politik, ekonomi maupun budaya. Selain itu masyarakat mengalami perubahan perilaku di antaranya dalam berkomunikasi. Komunikasi merupakan hal yang penting dalam kehidupan. Seiring dengan perkembangan zaman, komunikasi mengalami perkembangan dengan cepat. Komunikasi yaitu upaya penyampaian pesan kepada manusia untuk menemukan kesamaan makna. Komunikasi pada zaman dahulu dilakukan melalui surat, telegraf, aktivitas komunikasi tersebut membutuhkan waktu beberapa hari agar pesan dari komunikator sampai kepada komunikan. Namun sekarang ini kita dapat menikmati teknologi komunikasi modern seperti telepon, handphone, internet. Komunikasi pun dapat dilakukan dengan menggunakan alat komunikasi 
seperti media sosial. Media massa didefinisikan sebagai sistem untuk memindahkan dan menerima informasi dan hiburan secara personal. Media massa sekarang ini menghadapi perkembangan kemajuan yang signifikan. Bukan hanya media massa mainstreaming yang exist tetapi muncul media online dengan kecanggihan teknologi dan tak terbatas jangkauan memberi dan menerima informasi dari berbagai penjuru dunia (borderless). Saat ini kita menghadapi era kelimpahan komunikasi (communicative abundance), ditandai dengan melimpahnya informasi melalui beragam kanal komunikasi yang dimiliki warga. Tidak hanya bergantung pada media arus utama (mainstream media) seperti televisi, koran, radio melainkan juga media sosial. Media sosial penetrasi ke ruang-ruang personal nyaris tanpa batas. Kita menyadari era kemunculan komunikasi dimana media cetak dan penyiaran mulai kehilangan tempatnya sebagai saluran utama komunikasi. Informasi era sekarang ini banyak disebarluaskan melalui media online.

Di dunia internet atau media massa online muncullah istilah the Virtual Community yang menekankan adanya kualitas dari komunitas virtual. Ini menjadi persoalan tidak hanya di media massa online tetapi persoalan juga di media cetak dimana kualitas konten dan audiensi informasi yang mulai dipertanyakan. Misal munculnya fenomena Hoax dan Fake News di dunia informasi terhadap media online. Hal ini dapat terjadi salah satu penyebabnya banyaknya kesempatan masyarakat untuk memproduksi informasi dan berita yang dibuat tanpa batas. Dimana, kapan saja dan ke mana saja informasi bisa disampaikan melalui Computer Mediated Communication yaitu komunikasi yang dilakukan melalui komputer dalam hal ini dengan internet yang memberikan makna untuk membuat publik aktif dan tergugah untuk mengikuti era kemajuan.

Permasalahan utama adalah bagaimana dosen KPI dan mahasiswa KPI bisa memahami berita atau informasi bohong atau lebih dikenal dengan Hoax dan Fake News atau palsu yang disajikan media online menjadi fenomena. Setelah mereka tahu, bagaimana mereka menyikapi disinformasi tersebut? Jika mereka belum tahu, sebaiknya mereka tidak menyikapi, apalagi merespons atau mengomentarinya karena mereka belum tahu, duduk persoalannya. Dosen dan mahasiswa KPI menghindari dari jebakan dari disinformasi tersebut. Mereka sebaiknya cerdas menanggapi disinformasi tersebut.

Keberadaan internet juga memudahkan manusia untuk berinteraksi dengan orang lain tanpa harus merasa terhalang oleh jarak. Menurut Graham, interactivity merupakan salah satu cara yang berjalan di antara pengguna dan mesin (teknologi) dengan memungkinkan para 
pengguna maupun perangkat saling terhubung secara interaktif. Interaksi merupakan salah satu karakter media siber sebagai alat komunikasi1. Melalui media siber setiap manusia dapat saling terhubung dalam waktu yang bersamaan. Bahkan penggunaan media siber dapat mewakili keterlibatan pola komunikasi, yang semula hanya dapat berkomunikasi secara langsung atau face to face. Adapun jenis-jenis media siber diantaranya: Website, Email, Blog, Wiki, Broadcasting, Peer to peer, dan Media sosial.

Hoax dapat dipahami sebagai penipuan ke publik. Hoax menggunakan media sosial dengan karakteristik menjangkau khalayak luas, terkenal, dan tentunya masif. Fenomena semakin maraknya informasi hoax dapat disebabkan oleh semakin maraknya individu manusia memiliki dan menggunakan produk New Media seperti Facebook, Twitter, Instagram, group Whatsapp (WA), blackberry messenger (BBM), dll. Hoax dan Fake News memiliki perbedaan makna, kalau Hoax merupakan berita yang tidak jelas asal usulnya atau sumbernya yang masih simpang-siur, sehingga belum jelas kebenarannya. Sedangkan Fake News merupakan berita palsu atau sudah terbukti tidak benar yang dikabarkan oleh media massa resmi. Hal ini terjadi dengan adanya keberadaan media massa cetak dan buku bergeser dengan hadirnya teknologi informasi yang menyediakan tulisan, gambar, dan juga suara dalam satu paket multimedia. Namun yang menjadi persoalan adanya kurang rasa tanggung jawab pribadi sebagai produsen informasi tentang kebenaran sebuah berita atau informasi yang disebarluaskan kepada pembaca. Akibatnya muncullah berita Hoax dan Fake News di media massa yang banyak membawa dampak negatif. Hal yang patut diwaspadai akan hal tersebut adalah meminimalisasi risiko kemanusiaan dibawah perubahan tersebut, karena yang dikhawatirkan adalah hilangnya nilai kemanusiaan yang dikarenakan tidak adanya dialog interpersonal sebagai penyambung kemanusiaan. Pelaku Hoax dan Fake News misalnya, membuat berita yang fiktif dan disebarluaskan ke publik tanpa mempertimbangkan rasa tanggung jawab kemanusiaan terhadap kehidupan berbangsa dan bermasyarakat. Misalnya memunculkan konflik SARA, perpecahan golongan, dll. Pelaku Hoax dan Fake News seperti ini disebut "shipboard syndrome" yaitu suatu perasaan yang muncul pada pengguna yang tidak pernah berjumpa secara nyata. Pengguna merasa tidak punya rasa imun, hal ini menyebabkan adanya rasa disinhibited dan potensial lebih berani atau tepatnya tak terkendali dalam memproduksi sebuah informasi yang akan 
disebarluaskan ke publik. Fakta semakin maraknya Hoax di media sosial dan Fake News di media online menjadi persoalan kita bersama untuk diketahui sebagai krisis yang harus kita selesaikan, solusi apa yang bisa kita lakukan dalam menghadapinya. Fenomena seperti apa di dunia media massa.

\section{Diskusi}

Tabel 1

Pengetahuan, Sikap, Dan Tindakan Dosen dan Mahasiswa KPI terhadap Disinformasi

\begin{tabular}{lllll} 
Temuan & \multicolumn{2}{l}{ Pengetahuan } & Tindakan \\
Subjek 1 dosen & Bisa membedakan Tabayun terhadap Mengecek dan \\
AR & & hoax, fake news, fakta dari kedua mencari data dan \\
& dan disinformasi belah pihak & fakta dari semua \\
& karena ia pernah & pihak \\
& training oleh & \\
& UNESCO bekerja \\
& sama dengan UGM
\end{tabular}

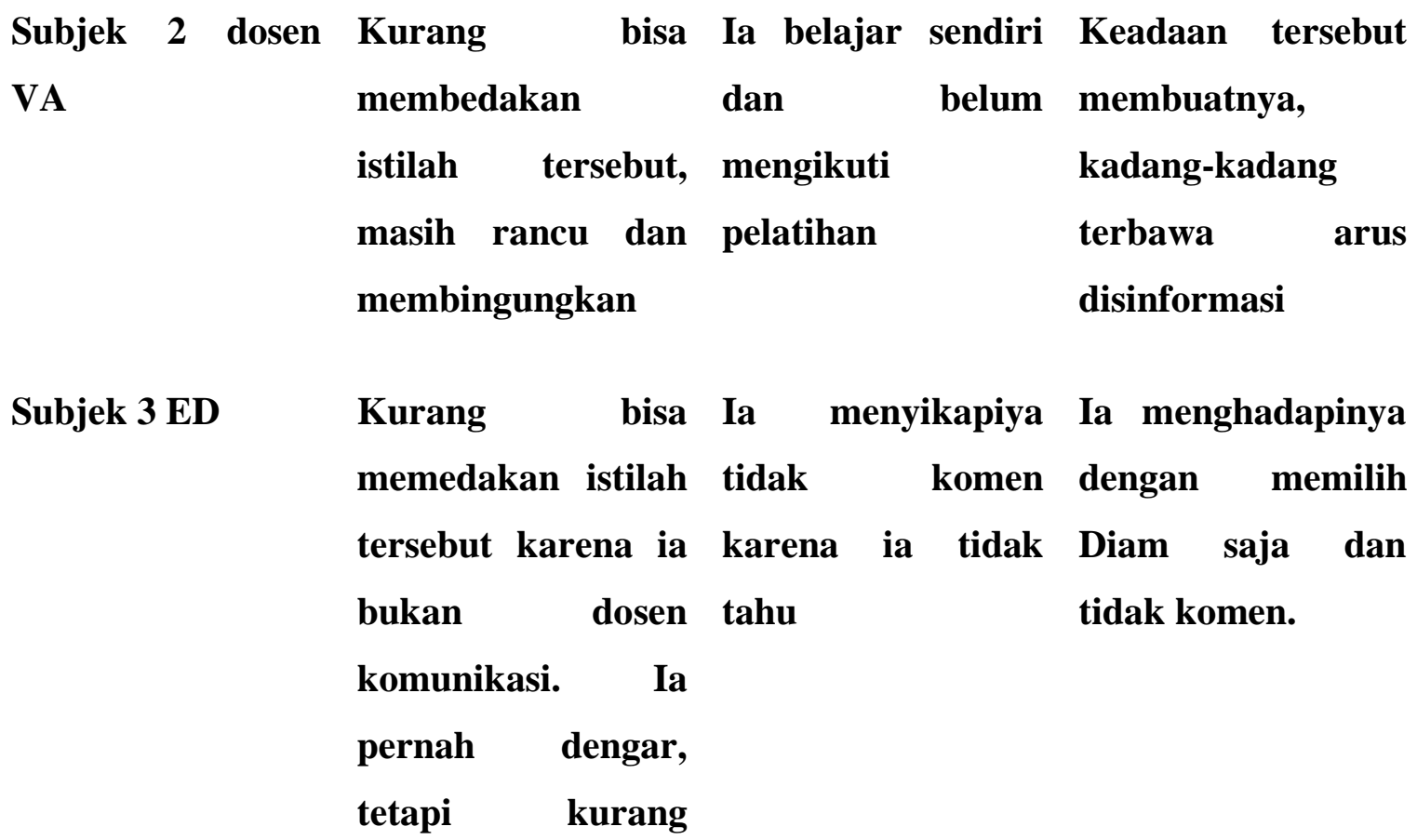


mencari tahu
isilahnya

Subjek 4 EV

$\begin{array}{lrlrl}\text { Kurang } & \text { bisa } & \text { Ia } & \text { sering } & \text { Ia memilih diam } \\ \text { membedakan } & & \text { tergelincir dengan ketika ia sadar } \\ \text { istilah hoax, fake } & \text { berita tersebut dan bahwa itu terjadi } \\ \text { news, } & \text { dan } & \text { ia menyesal ketika disinformasi. } \\ \text { disinformasi } & \text { ia tahu bahwa Ketika ia lengah, ia } \\ & \text { berita itu faktanya terbawa arus. } \\ & \text { tidak akurat dan } \\ & \text { belum Tabayun ke } \\ & \text { semua pihak. }\end{array}$

Subjek 5 WA Lebih memahami Ia sangat hati-hati Ia menghadapinya karena ia youtuber berkaitan secara profesional dan ia harus tahu informasi jika ia menemui UU berkaitan disinformasi. Ia dengan penyiaran mencari tahu dan media massa sumber data dan fakta. Tabayun semua pihak.

Subjek 6 RI

$\begin{array}{llllr}\text { Ia } & \text { sedikit } & \text { Walaupun } & \text { ia } & \text { Ia kadang-kadang } \\ \text { memahami } & \text { istilah } & \text { kurang paham, ia } & \text { mencari } & \text { tahu } \\ \text { tersebut } & & \text { sangat berhati-hati } & \text { faktanya. } & \text { Ia } \\ & \text { terhadap } & \text { verifikasi faktanya } \\ & \text { disinformasi } & \text { dari semua pihak. } & \\ & & \text { Ia aktif } & \text { ketika } \\ & & \text { mendapat } & \\ & & \text { informasi }\end{array}$




\section{WASPADA: MEDIA SOSIAL SALURAN INFORMASI HOAX}

Perkembangan kemajuan teknologi yang dialami sekarang ini membawa implikasi yang cukup signifikan dalam perkembangan media massa. Media massa yang awalnya hanya berbasis cetak dan penyiaran, mulai melirik bahkan merambah ke media massa online sebagai ranah baru yang sangat menjanjikan. Maka dengan konsep jurnalisme konvensional yang berbeda dengan konsep jurnalisme online, media online menghadirkan kebaruan ke dalam dunia pemberitaan dan jurnalistik. Bukan hanya misalnya mengadaptasikan atau melakukan inovasi media cetak menuju layar datar, tetapi juga menggabungkan cetak, suara, dan gambar artinya melakukan konvergensi atau penyatuan dan perpaduan satu sama lain. Jurnalisme online muncul sebagai pesan atas perkembangan teknologi sekaligus pesan untuk jurnalisme di masa depan. Internet secara bertahap menjadi bentuk media baru (New Media), semua media lama harus menyesuaikan dengan kondisi pasar dan model bisnis yang baru. ${ }^{2}$ Salah satunya surat kabar yang hampir seluruh perusahaan media surat kabar konvensional melakukan digitalisasi media. Tidak hanya surat kabar, televisi dan radio pun kini hadir secara streaming internet.

Munculnya internet tidak hanya memengaruhi eksistensi media massa tetapi juga media sosial yang semakin berkembang. Kemajuan teknologi informasi yang begitu pesat, membuat arus informasi semakin tak terbendung. Harga smartphone yang terjangkau oleh semua kalangan, juga mempermudah semua orang untuk dapat mencari dan menyebarluaskan informasi apapun, di mana pun, dan kapan pun (Borderless). Inovasi teknologi komunikasi terhadap media berbasis internet pada kenyataannya adalah cerminan dari bangkitnya bentuk baru komunikasi. Karena informasi yang didapat dari internet bersifat langsung dan cepat.3 Kecepatan untuk mengakses informasi juga menyebabkan kurangnya ketelitian dalam menerima informasi yang didapat. Dengan mudahnya seseorang menerima informasi tanpa adanya cek and recek bisa menimbulkan kesalahpahaman.

Berita, informasi yang belum tentu kebenarannya atau Hoax kini semakin ramai berseliweran tanpa ada yang bisa membendungnya. Hoax menjadi fenomena yang cukup meresahkan. Semakin berkembang adanya beragam situs media sosial di internet seperti instagram, fecebook, twitter, youtube, whatsapp, google plus dan sebagainya. Keunggulan dari

\footnotetext{
${ }^{2}$ Atwar Bajari, Sahat Sahala Tua Saragih, Komunikasi Kontekstual. Teori dan Praktik Komunikasi Kontemporer, (Bandung: PT. Remaja Rosdakarya , 2011), h. 467
} 
situs atau aplikasi media sosial adalah desain multiplatform, yaitu dapat diakses dan terhubung di berbagai perangkat digital. Sekitar 80 juta penduduk Indonesia yang memanfaatkan teknologi internet, terdapat 70 juta pengguna yang merupakan pelanggan internet mobile. Sebagian besar pengguna internet mobile tersebut hanya menggunakan fungsi internet untuk chatting dan mengakses situs media sosial, bukan mengakses data baik mengunduh atau menggugah informasi penting di internet.4 Konsekuensinya adalah konstruksi ruang virtual yang diproduksi teknologi membuat manusia hanyut di dalamnya dan terinterupsi dari ruang realitasnya. Di berbagai media sosial misalnya grup whatsapp, facebook, twitter, dan media sosial lainnya begitu sesak dengan berita hoax. Jika sebelumnya media sosial hanya digunakan untuk posting status dan foto pribadi, atau sekadar bekenalan dengan penghuni dunia maya, kini media sosial memiliki kekuatan lebih dari sekadar itu. Media sosial dari ruang eksistensi individu seseorang yang dibagikan ke publik berubah maknanya dengan kepentingan tertentu misalnya ekonomi, politik, sosial, keagamaan. Semakin melimpahnya informasi dan komunikasi tidak berarti membuat orang serba tahu dan tercerahkan. Era kelimpahan komunikasi justru dipandang telah membawa kontradiksi baru dan menciptakan konflik baru di masyarkat.

Krisis hoax di media sosial misalnya terjadi ketika pengguna internet mobile dalam handphone android atau IOS nya mengunduh sesuatu yang hanya sekadarnya saja, bukan informasi atau berita penting yang mereka akses. Kebanyakan pengguna internet mobile hanya menerima pesan yang kemudian tanpa berpikir panjang memforward pesan tersebut ke kontak yang lain dan menjadi viral atau trending topic. Hal ini menunjukkan bahwa pengguna internet mobile tersebut terjebak dengan simulasi realitas sosial yang sesungguhnya terkadang berbanding terbalik dengan fakta. Artinya ini memalsukan relasi sosial menjadi simulasi realitas sosial. Suatu realitas yang dibangun dari model tanpa referensi, sehingga ilusi, fantasi maupun citra layar dari komputer maupun smartphone saat berkomunikasi menjadi tampak nyata5. Semakin kita gencar terhubung dengan ruang virtual, maka kita hidup dalam dunia hiperrealitas yaitu dalam keadaan tidak mampu membedakan antara kenyataan dan fantasi. Fenomena ini menurut penulis merupakan problematic karena hiperrealitas menjauhkan kita dari kehidupan yang nyata dan dapat mengakibatkan kematian realitas. Socialmediatoday.com merilis data

4 Didik Purwanto, Dominasi Penggunaan Internet Mobile, (http://tekno.kompas.comread/2012/02: 182) 5 Yasraf Amir Piliang, Posrealitas: Realitas kebudayaan dalam era postmetafisika, (Yogyakarta: Jalasutra, 2004), h. 21 
sebanyak $85 \%$ pengguna menjadikan Facebook dan Twitter sebagai sumber pertama di pagi hari. Facebook digunakan 1,7 miliar orang per bulan dan pengguna harian Twitter sekitar 140 juta orang. jangan heran jika dua platform media sosial itu dijadikan saluran penyebaran informasi, baik yang kredibel maupun hoax.

Media sosial menjadi saluran yang banyak digunakan untuk melakukan penyebaran hoax. Tak jarang provokasi dan ungkapan kebencian banyak dilontarkan di media sosial, baik itu untuk kepentingan politik maupun kepentingan perorangan untuk saling menjatuhkan. Ketika propaganda begitu mainstream dilakukan di media massa, media sosial menjadi pilihan. Selama ini penyebar informasi hoax memang memiliki banyak modus. Misalnya, situs penyebar informasi hoax dan fitnah membuat akun di media sosial. Dari situ, dia memposting tautan situsnya di media sosial dengan memberi keterangan yang bombastis. Yang lebih parah, sebagian netizen langsung menyebarkan tautan itu ke akun masing-masing bahkan tanpa membaca isi beritanya. Di momentum Pilkada misalnya, muncul buzzer-buzzer yang bertugas menyebarkan informasi-informasi atau pesan yang berupa hasutan atau provokasi. Biasanya berupa akun-akun personal yang baru saja dibuat. Akun-akun itu menyebarkan pesan hoax dari akun utama, yang pada akhirnya terbaca oleh netizen lain. Lebih parahnya pesan tersebut mengandalkan judul yang bombastis untuk memainkan psikologis netizen. Hoax sering memanfaatkan ketidaktahuan orang, termasuk rasa takut dan kekhawatiran. Cukup mengejutkan betapa pesan dan informasi yang beredar dari netizen di media sosial sangat cepat, dalam hitungan di bawah 5 menit dari kejadian sesungguhnya, informasi sudah menyebar di media sosial, bahkan mendahului portal berita resmi. Namun, pada akhirnya kesimpangsiuran ini harus dihadapi agar ke depannya menjadi tahapan untuk terus berproses lebih baik dalam menerima sebuah informasi.

Fase krisis akan maraknya pesan dan informasi hoax pun direspons oleh pemerintah demi melindungi masyarakat. Berbagai cara dilakukan mulai dari memblokir situs hoax, hingga membuat website resmi yang berisi berita-berita hoax yang dapat diakses di url https://data.turnbackhoax.id. Web ini bukan untuk menyebarkan informasi hoax, tetapi untuk memberikan edukasi kepada masyarakat mengenai berita mana saja yang beredar di masyarakat, yang termasuk berita bohong atau hoax. Difusi pesan di media sosial misalnya di Twitter yang merupakan kanal deteksi isu. Kondisi pada saat sekarang ini hanya twitter yang masih menyediakan fasilitas "search" ke seluruh status/twit yang dimilikinya. Sedangkan untuk 
Facebook dan instagram hanya menyediakan akses terhadap Public Page aja. WhatsApp tidak dapat ditangkap percakapan di dalamnya. Namun, melihat pola Virality dan resonansi antara Platform media sosial, kita dapat menggunakan twitter sebagai 'Proxy' untuk mengetahui apa yang terjadi di media sosial.

Akibat adanya fenomena hoax di media sosial, publik mulai tidak percaya pada media mainstream dan juga ketidakpercayaan publik pada Pemerintah. Untuk mengatasi hal tersebut dapat dilakukan pemblokiran tetapi tidak akan efektif juga. Semakin diblokir, pelaku hoax akan membuat platform baru di Media sosial. Hal ini terjadi akibat adanya kebebasan dan berekspresi, berpendapat dan pesta demokrasi dalam media massa, sehingga kondisi seperti ini menjadi ladang subur pesta hoax. Pelaku hoax sekarang semakin terang-terangan misalnya munculnya spanduk-spanduk berisi Hoax: AHY dan FPI Haramkan Acara Wayang Kulit, dll. Ada juga pesan melalui WhatsApp tentang Partai Komunis Indonesia (PKI), isu ideologi menjadi komoditas politik di semua pihak. Informasi menyebar di media sosial sangat terpolarisasi. Fenomena Hoax di masyarakat itu mengganggu publik dan opini publik yang terbentuk di masyarakat. Hal ini dapat terjadi karena banyak situs opini yang tendensius, bias dan menyerang. Hal ini berkembang jauh lebih subur dan terbuka daripada Hoax. Faktor yang sangat memengaruhi semakin suburnya Hoax adalah adanya Konstelasi politik, selain itu juga menyuburkan terciptanya rumor, dll. Selain itu faktor ketidakpercayaan (distrust) terhadap pemerintah dan media mainstream turut mendorong munculnya berita dan opini yang bias dan mempolarisasi.

\section{KOMUNIKASI VIRTUAL}

Komunikasi merupakan bagian terpenting dan vital dalam kehidupan manusia. Tanpa komunikasi ma menyangkut persoalan-persoalan yang ada kaitannya dengan substansi interaksi sosial orangorang dalam masyarakat, termasuk konten interaksi (komunikasi) yang dilakukan secara langsung maupun menggunakan media komunikasi cetak, elektronik, digital yang terhubung dengan internet.

\footnotetext{
${ }^{6} 6$ Rulli, Nasrullah, Komunikasi Antarbudaya di Era Budaya Siber, (Jakarta Kencana Prenada Media Group, 2012)h.1
} 
Komunikasi virtual merupakan komunikasi (proses penyampaian dan penerimaan pesan) yang terjadi melalui telepon atau pikiran orang yang dituliskan dalam buku) dan ritual yang membangkitkan masa lalu dan membuat massa sekarang tidak ada.

Perkembangan internet tidak lain karena internet merupakan media komunikasi manusia yang penting. I orang lain tanpa harus merasa terhalang jarak. Interaksi atau interactivity merupakan salah satu cara yang berjalan diantara pengguna dan mesin teknologi dengan memungkinkan para pengguna maupun perangkat saling terhubung secara interaktif.7 Interaksi merupakan salah satu karakter media siber sebagai alat komunikasi. Internet sudah menjangkau semua praktik sosial. Mengubah cara berkomunikasi manusia dan mengubah semua praktik sosial.

Dalam komunikasi, kita mengenal istilah virtual community yang menurut Rheingold (1995) merupakar yang terbentuk di ruang siber. Virtual community merupakan komunitas yang terbentuk dari komunikasi yang dimediasi oleh komputer (Communication Mediated Computer). Anggota komunitas dapat berbagi pengalaman serta menikmati konten yang disediakan pada media siber. Bila pada komunitas di dunia nyata dibutuhkan pertemuan secara tatap muka untuk menjalin komunikasi, namun di komunitas virtual tidaklah diperlukan pertemuan secara tatap muka. Bahkan komunitas cenderung tidak perlu saling mengenal satu sama lain untuk tergabung dalam komunitas. Virtual communities adalah kesatuan sosial yang muncul dari jaringan sosial ketika sejumlah orang berdiskusi dalam waktu yang cukup lama, dengan perasaan yang cukup untuk hubungan personal di dunia maya. 8

Istilah dunia virtual sering disebut dengan dunia cyberspace yang merupakan ruang simbolis yang menja

a. Tingkat individual dunia cyberspace telah menciptakan perubahan mendasar terhadap pemahaman seseorang tentang identitas

b. Tingkat antar individual perkembangan komunitas virtual di dalam cyberspace telah menciptakan relasi-relasi sosial yang bersifat virtual di ruang-ruang virtual

c. Tingkat komunitas cyberspace diasumsikan dapat menciptakan satu model komunitas demokratis dan terbuka yang disebut komunitas imajiner (imaginary community).

\section{FENOMENA FAKE NEWS SEBAGAI ORGANISASI BISNIS BARU DI MEDIA MASSA}

7 Fita, Fathurokhmah , Komunikasi Komunitas Virtual dan Gaya Hidup Global Kaum Gay di Media Sosial, (Jakarta: Jurnal Kajian Dakwah dan Kemasyarakatan UIN Syarif Hidayatullah Jakarta, 2019) hal 40-41

8 Fita, Fathurokhmah, Komunikasi Komunitas Virtual dan Gaya Hidup Global Kaum Gay di Media Sosial, hal. 41 
Fake News merupakan berita palsu atau sudah terbukti tidak benar yang dikabarkan oleh media massa resmi. Fake News misalnya terjadi ketika pemberitaan tentang Paus mendukung Donal Trump AS di tahun 2016 beredar di media online. Ada lagi sebuah penelitian yang dilakukan Massachuseet Institut Technology bahwa informasi palsu lebih cepat menyebar dibandingkan dengan informasi yang benar dan akurat. Potensi pemalsuan berita atau Fake News yang ada dalam proses produksi berita secara profesional itu bisa ditemukan. Kita dapat menganalisis pada tingkat mikro yaitu pekerjaan wartawan diposisikan menganut paham liberal, dan analisis sosial ekonomi politik juga dapat kita lakukan pada tingkat makro juga, sedangkan kerangka kerja berkembang di tingkat mezzo dari lembaga wartawan dan bidang keahlian. Ini menekankan pada peran organisasi berita dan persaingan industri di media massa. Berita sebagai komoditas, karena dikelola oleh perusahaan komersial yang bersaing. Ini adalah tentang kebutuhan untuk memproduksi dan mendistribusikan produk pasar secara massal dan hal baru dengan menggunakan sumber bahan baku yang tidak menentu dan tidak dapat diandalkan, setiap hari. Ini ditujukan untuk pasar konsumen yang frickle, cepat berubah, skeptis, dan secara bertahap menurun kualitas dari berita itu sendiri. Berita adalah apa yang tidak dapat diprediksi dan peristiwa apa yang langsung terjadi di lapangan. Ini menjadi persoalan bagi wartawan yang dihadapkan pada kepentingan industry yang ingin mempermudah proses jalur idealis wartawan menjadi jalur liberal dengan menuliskan berita berdasarkan peristiwa dan tindakan wartawan secara mentah tanpa mengikuti kaidah jurnalistik, tidak diproses sesuai fakta, kemudian dipilih, ditafsirkan dan dibentuk kembali menjadi berita atau disebut recycle of news. Ini adalah layanan yang ditawarkan oleh organisasi berita bisnis kepada konsumen. Organisasi berita memilih apa yang paling menarik, bernilai berita untuk publik dan menyampaikan cerita dengan cara yang masuk akal, sederhana dan menarik.9

Industri berita mengalami penurunan secara dramatis. Jurnalis senior menemukan solusi inovatif yang memungkinkan mereka terus menghasilkan jurnalisme yang dapat terus melayani publik dan menguntungkan. Tetapi pada kenyataannya, hasil yang paling umum adalah kualitas yang lebih buruk, berita buruk, audiens tidak tertarik dan tidak percaya lagi pada berita akibat Fake News, lebih banyak kerugian finansial. Masalah yang dominan adalah menurunnya pendapatan yang menyebabkan semakin meningkatnya kendala sumber daya yang dikenakan pada wartawan. Upaya untuk tetap untung, organisasi berita menaikkan harga di atas inflasi,

9 Aeron, Davis, Political Communication: a New Introduction for Crisis Times, (USA: Polity Press, 2019), h. 80. 
mengurangi staf editorial, dan menegakkan berbagai langkah pemotongan biaya. Pada 2012, banyak industri di AS dan Eropa berjuang untuk bertahan hidup, dengan banyak organisasi media cetak dan penyiaran runtuh atau hampir bangkrut. Di Inggris, delapan surat kabar harian nasional teratas, kehilangan hampir 35\% penjualan antara 2010 dan 2016. Pada tahun 2016 saja, mereka kehilangan $13 \%$ dari iklan mereka.10

Dalam jurnalisme online terdapat tiga hal yang dapat diidentifikasi sebagai bahasa operasinya, yaitu hypertextuality, multimediality, interactivity. Hipertektualitas dimaksudkan di media online bukan berarti melibatkan banyak teks tetapi lebih pada persoalan hyperlink yang terbentuk karena banyaknya teks terhubung atau kaitannya dengan informasi terdekat. Dengan hyperlink ini mereka yang mengakses berita melalui online bisa mendapatkan informasi yang lebih dengan sudut pandang yang lebih beragam. Hipertekstualitas ini menawarkan cukup banyak informasi daripada yang dibutuhkan oleh para pengaksesnya. Fenomena ini sebetulnya merupakan karakter bawaan dari munculnya World Wide Web (www). Sifat ini diadaptasi oleh situs-situs penyedia informasi (portal berita) untuk menyediakan berita asli sesuai dengan yang di Klik atau diinginkan oleh pembaca, sekaligus menghadirkan aspek lain yaitu Link berita sejenis, atau teks berita yang asli atau dokumen pendukung lainnya. Hal inilah yang menyebabkan ledakan informasi menjadi sesuatu yang tidak dapat dihindarkan. Sedangkan Multimediality dimaknai sebagai praktik penggabungan atau konvergensi di media. Integrasi terjadi antara teks, audio, gambar, dll. Hal ini berimplikasi pada kerja jurnalis online lebih cepat dan tidak dibatasi space dan kolom. Interactivity dimaknai dalam jurnalisme online, pertama aktivitas mekanis yang berarti protokoler dalam internet. Kedua, aktivitas interaktif yang berarti interaksi yang terjadi dalam internet.

\section{WARTAWAN PLURALIS LIBERAL DIHADAPKAN PADA PASAR INDUSTRI}

Teori pluralis liberal itu menghubungkan jurnalisme profesional dengan prinsip-prinsip ruang publik, pe pluralis dan kebenaran fakta objektif berita, keduanya difasilitasi dengan menyediakan forum untuk debat publik.

Jurnalisme profesional gaya Anglo-Amerika dianggap sebagai model praktik modern yang baik dan id sejarah atau cerita masa lampau (Hallin dan Mancini, 2011; Dunia Jurnalisme, 2016). Dalam setiap kasus, wartawan berhasil mengungkap korupsi atau bekerja sama dengan pelapor, seperti

10 Aeron, Davis, Political Communication: a New Introduction for Crisis Times, h.84 
Edward Snowden dan Wikileaks, untuk mempublikasikan peristiwa. Di negara-negara yang kurang tenang, atau rezim otoriter, ada banyak reporter yang berani mempertaruhkan hidup mereka setiap hari untuk menyelidiki dan meminta pertanggungjawaban. Wartawan atau sosiolog media yang berpikir jernih menyatakan bahwa peliputan harus benar-benar objektif, berita cerminan kepentingan masyarakat seutuhnya. Wartawan memiliki ideologi pekerjaan dari profesinya (lihat diskusi dalam Schudson dan Anderson, 2009). Ideologi pekerjaan profesi wartawan mengandung nilai yang harus dipegang wartawan untuk melayani publik, menulis berita dengan objektif, akurasi, imparsialitas, otonomi, dan pencarian kebenaran. Nilai positif itu dilanjutkan adanya pendidikan spesialis, asosiasi profesional. Survei berkala jurnalis di seluruh dunia (mis. World of Journalism, 2012-16), mengungkapkan bahwa jurnalisme semakin banyak dikelola oleh lulusan dengan pendidikan profesional.

Cita-cita jurnalisme publik dibuat melalui praktik, prosedur yang ditanamkan kepada wartawan melalı memperbesar peran wartawan pada publik, wartawan menginternalisasi norma profesional, operasi prosedur, menerima peristiwa, penempatan prioritas, lebih banyak adanya otonomi wartawan, dan peningkatan hierarki editorial. Reporter belajar cara mereproduksi debat dengan berbagai metode. Dengan demikian, sumber-sumber ahli, otoritatif dicari untuk memberikan fakta, memberi komentar penjelasan, prinsip-prinsip pluralis dengan beragam narasumber dari berbagai pihak adalah syarat utama untuk mencapai berita cover both sides, netral, yang berarti partai-partai oposisi dilaporkan bersama pemerintah, serikat pekerja dan kelompok penekan di samping perusahaan, dan sebagainya. Cita-cita profesional dan pasar memastikan pluralisme direproduksi di skala lain. Dalam hal publikasi harus seimbang misalnya siaran highbrow ada juga siaran lowbrow.

\section{PRAKTEK PROPAGANDA MEDAI DALAM MEMPRODUKSI FAKE NEWS}

Teori ekonom politik kritis (Herman dan Chomsky, 2002; Curran, 2011; Bagdikian, 2014; Fuchs dan N seperti kelompok (atau kelas) korporasi, politik, dan militer. Berita secara keseluruhan menyampaikan gambaran palsu masyarakat, mereka mengendalikan ruang publik. Teori ini awalnya dari Max and Engels (1846): Munculnya ide kelas penguasa yang hadir di setiap masa, munculnya ide berkuasa, kelompok yang menempati kelas tertentu memiliki fasilitas sarana untuk produksi berita, memiliki kontrol terhadap wartawannya. Selama dua abad terakhir, berita yang diproduksi, disebarluaskan sesuai dengan perintah penguasa, kepentingan ekonomi politik 
yang dipengaruhi sistem instruksi Top-down (Curran, 2002) dan melalui tahapan filter (Herman dan Chomsky, 2002) di mana konten dibentuk oleh yang kuat. Reporter berita dan organisasi menciptakan sesuatu yang lebih dengan melakukan propaganda atau membuat berita 'palsu'.

Filter pertama Ownership atau kepemilikan, pemilik utama berita adalah pemerintah dan perusahaan bes dapat menyebabkan kegagalan untuk menyelidiki kasus misalnya perusahaan dan sekutu politik tertentu atau promosi kebijakan, partai, dan bisnis yang terang-terangan. Bisnis media besar didorong oleh motif keuntungan dan kepentingan politik mereka sendiri. Mereka bertanggung jawab atas penguasa, pemegang saham eksekutif, dan anggota dewan perusahaan. Pemilik seperti Michael Bloomberg di AS, Silvio Berlusconi di Italia, Carlos Slim di Meksiko, Barclay Brothers di Inggris, dan Rupert Murdoch, jelas memiliki agenda politik mereka sendiri dan pengaruh yang lebih luas. Filter kedua Funding adalah pembiayaan atau pemasukan media termasuk periklanan. Pengiklan perusahaan besar dapat menekan langsung, terbuka kepada pemilik media tentang topik berita yang diinginkan pengiklan (Thompson, 2000; Thussu, 2008; Curran, 2011). Pada tingkat yang tidak terlalu tinggi, iklan juga membentuk konten berita dengan mempromosikan berita, format, dan minat warga negara tertentu terhadap yang lain. Kebutuhan untuk menarik, dan memikat hadirin, juga membuat para pengumpul berita lebih fokus pada cerita-cerita konflik, minat manusia, selebritas, sensasionalisme, dan skandal. Filter ketiga adalah Sourcing adalah sumber penyedia informasi. Elite yang kuat dan sumber daya yang baik mampu mengerahkan pengaruhnya sebagai sumber berita utama. Wartawan biasanya mencari orang-orang yang berada di puncak pemerintahan dan bisnis karena mereka adalah kepentingan umum dan secara teratur tampil dalam berita. Mereka juga sering menjadi sumber informasi yang relevan dengan peristiwa. Dengan demikian, akses media ke politisi terkemuka dan ruang legislatif (Kurtz, 1998; Barnett dan Gaber, 2001), dan para pemimpin dan zona militer (Tumber dan Palmer, 2004; Thussu dan Freedman, 2012), semuanya dapat diberikan atau ditarik sesuai. Sebagai pemasok informasi, sumber dapat 'memutar' materi yang mereka sajikan. Filter keempat Flak adalah 'kritik' pendisiplinan media. Editor media yang dipekerjakan memberikan tekanan publik kepada jurnalis, merusak kredibilitas wartawan; sesuatu yang dilakukan oleh para pemimpin populis agresif hari ini secara teratur. Filter kelima Anti-komunisme adalah mekanisme kontrol media. Dalam hal ini, kritik yang lebih besar terhadap ancaman komunis meliputi cakupan umum urusan 
luar negeri dan masalah keamanan. Filter anti-komunisme berhubungan dengan ancaman alternatif yang dirasakan terhadap kapitalisme atau demokrasi Barat.11

Etika seorang muslim berkomunikasi dengan orang yang dituakan seperti kepada orang tua, guru, dosen, dan sebagainya agar menggunakan kata yang sopan dan santun.

1. Komunikasi yang perkataannya benar, jujur, dan tidak berbelit-belit kepada generasi muda disebut Qaulan Sadidan, QS. An-Nisa (4) ayat 9:

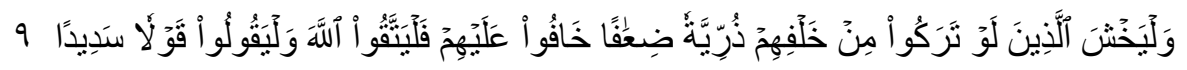

Ayat 9: Dan hendaklah takut kepada Allah orang-orang yang seandainya meninggalkan dibelakang mereka anak-anak yang lemah, yang mereka khawatir terhadap (kesejahteraan) mereka. Oleh sebab itu hendaklah mereka bertakwa kepada Allah dan hendaklah mereka mengucapkan perkataan yang benar.

Seorang muslim berupaya meluruskan informasi yang dia terima dengan cara memeriksa kembali sumber informasinya. Jika terjadi penyimpangan/distorsi informasi, ia harus membiasakan tradisi pelurusan informasi sehingga ia tidak terjebak dengan distorsi informasi. Jika kita terbawa oleh distorsi informasi, maka kita akan masuk kedalam rekayasa orang yang membuat informasi itu.

Berhati-hati menyebar berita, dalam QS. An-Nur (24) ayat 19:

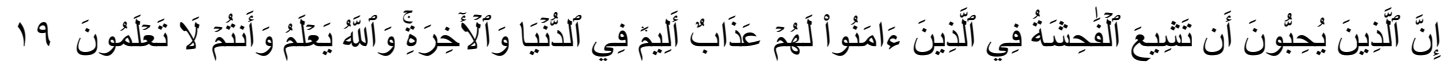
Ayat 19: Sesungguhnya orang-orang yang ingin agar (berita) perbuatan yang amat keji itu tersiar di kalangan orang-orang yang beriman, bagi mereka azab yang pedih di dunia dan di akhirat. Dan Allah mengetahui, sedang, kamu tidak mengetahui.

1. Seorang muslim dalam menyebar berita luruskan dahulu niatnya;

2. Ia ingin membangun komunikasi yang konstruktif atau komunikasi yang deskonstruktif/merusak;

3. Jika penyebar berniat melakukan kejahatan atau rekayasa di kalangan orang mukmin, maka bersiaplah mempertanggungjawabkan perbuatannya karena siksaannya sangat pedih baik di dunia maupun di akhirat;

11 Aeron Davis, Political Communication; A New Introduction for Crisis Times, h. 75-80 
4. Pikirkan matang-matang walaupun manusia tidak mengetahui, tetapi Allah SWT pasti mengetahui. Contoh pada zaman sekarang yaitu buzzer-buzzer yang terdapat di media sosial.

Penerima berita seharusnya memeriksa dulu sumber beritanya, dalam QS. AlHujurat (49) ayat 6:

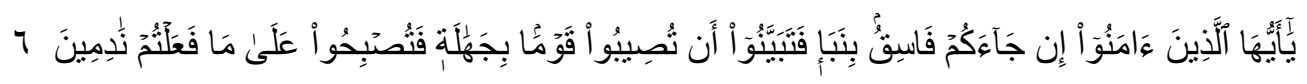

Ayat 6: Hai orang-orang yang beriman, jika datang kepadamu orang fasik membawa suatu berita, maka periksalah dengan teliti agar kamu tidak menimpakan suatu musibah kepada suatu kaum tanpa mengetahui keadaannya yang menyebabkan kamu menyesal atas perbuatanmu itu.

Seorang muslim tidak gegabah menyebarkan informasi baik melalui media sosial maupun media lainnya. Yang harus dilakukan adalah:

1. Selidiki dulu sumber beritanya;

2. Jangan berkomentar dahulu sebelum tahu sumbernya;

3. Setelah tahu sumbernya, bertanya dahulu kepada dua belah pihak yang diberitakan;

4. Berupaya membangun komunikasi yang konstruktif.

Pandangan Islam terhadap berita yang sensasional, gossip, dan semacamnya dalam QS. An-Nur (24) ayat 14-16:

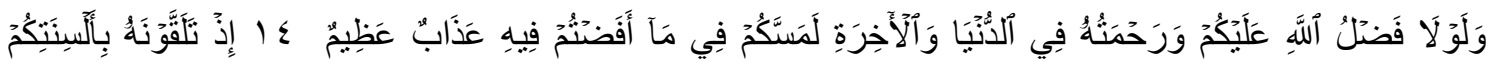

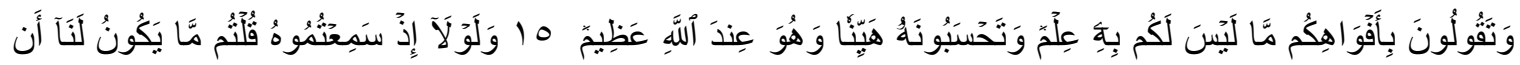

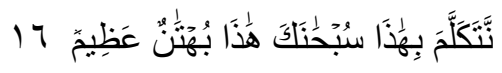

Ayat 14: Sekiranya tidak ada kurnia Allah dan rahmat-Nya kepada kamu semua di dunia dan di akhirat, niscaya kamu ditimpa azab yang besar, karena pembicaraan kamu tentang berita bohong itu.

Ayat 15: (Ingatlah) di waktu kamu menerima berita bohong itu dari mulut ke mulut dan kamu katakan dengan mulutmu apa yang tidak kamu ketahui sedikit juga, dan kamu menganggapnya suatu yang ringan saja. Padahal dia pada sisi Allah adalah besar. 
Ayat 16: Dan mengapa kamu tidak berkata, di waktu mendengar berita bohong itu: "Sekali-kali tidaklah pantas bagi kita memperkatakan ini, Maha Suci Engkau (Ya Tuhan kami), ini adalah dusta yang besar.

Keluarga muslim menghindari konflik diungkapkan di media massa maupun media sosial agar tidak jauh dari karunia Allah SWT. Jika ingin meningkatkan popularitas, pilihlah dengan cara-cara yang Islami seperti yang telah dijelaskan diatas. Acara infotainment sebaiknya mengangkat orang-orang yang berprestasi, memberikan inspirasi, motivasi, dan keluarga sakinah.

\section{B. PENUTUP dan KESIMPULAN}

Krisis Hoax dan Fake News harus kita hadapi dan kita temukan solusi yang tepat karena membawa efek publik yang benar sesuai dengan regulasi, terutama media online harus menjadi rujukan referensi pembaca untuk berita yang akurat dan cover both sides. Hoax yang terjadi di Media online terjadi di media sosial baik itu dilakukan oleh journalist online, citizen journalist bahkan netizen sebagai pelaku penyebarluasan berita bohong dan palsu. Dalam perspektif hukum, sifat media online yang berbeda dengan media konvensional, hal ini memunculkan konsekuensi etis maupun hukum yang berbeda pula. Sebagai medium penyampai pesan dan ranah kebebasan berekspresi, tentunya perkembangan jurnalisme online selayaknya memiliki aturan sendiri. Masalahnya sampai sekarang ini aturan hukum yang digunakan oleh pemerintah untuk mengatur jurnalisme online masih UU Pers. Aturan hukum yang dimiliki di Indonesia sangat parsial. Jurnalisme online dalam hukum media di Indonesia masih dipayungi dengan Undang-Undang No 40 tahun 1999 tentang Pers. Dalam pasal 1 ayat (1) Undang-Undang Pers disebutkan bahwa yang dimaksud dengan pers adalah lembaga sosial dan wahana komunikasi massa yang melaksanakan kegiatan jurnalistik meliputi mencari, memperoleh, memiliki, menyimpan, mengolah, dan menyampaikan informasi, baik dalam bentuk tulisan, suara, gambar, data dan grafik maupun dalam bentuk lainnya dengan menggunakan media cetak, media elektronik, dan segala jenis saluran yang tersedia. Undang-undang ini dinilai masih bisa diberlakukan untuk mengatur jurnalisme online, karena dalam pasal 1 undang-undang tersebut jurnalisme online masih masuk pengertian pers yang digagas oleh UU. Persoalan muncul dalam regulasi media online di Indonesia masih disamaartikan dengan regulasi media cetak dan media penyiaran padahal jurnalisme online memiliki karakter yang berbeda dengan jurnalisme konvensional. Regulasi 
media massa di Indonesia mengatur pelarangan penyebaran informasi atau berita berupa hal-hal yang menyerang kepentingan individu, pencemaran nama baik, pembunuhan karakter/reputasi seseorang, menyebarkan kebencian, rasialis, mempertentangkan ajaran agama, menyebarkan halhal tidak bermoral, mengabaikan kaidah kepatutan menyangkut seksual yang menyinggung perasaan umum dan perundungan seksual terhadap anak-anak Hal-hal yang bersifat kebohongan publik juga tidak diperkenankan misalnya melakukan kecurangan, tidak jujur, termasuk menyampaikan promosi atau iklan palsu. Yang terakhir adalah masalah hak cipta (copyright) dan hak atas karya intelektual (HAKI), masalah-masalah tersebut di media massa, media online cukup fundamental dan tidak boleh dilakukan. Langkah-langkah yang dapat dilakukan dalam menghadapi Hoax dapat dilakukan dari semua elemen yang terlibat. Misalnya Dewan Pers Indonesia; adalah sebuah lembaga independen di Indonesia yang berfungsi untuk mengembangkan dan melindungi kehidupan pers di Indonesia. Pembentukan Dewan Pers juga dimaksudkan untuk memenuhi Hak Asasi Manusia (HAM), karena kemerdekaan pers termasuk sebagai bagian dari HAM. Dewan Pers memiliki wewenang untuk menyelesaikan sengketa jurnalistik. Sebagai lembaga independen, Dewan Pers tidak memiliki perwakilan dari Pemerintah pada jajaran anggotanya. Yang dapat dilakukan oleh Dewan Pers misalnya terhadap Hoax yaitu melakukan Verifikasi media massa dengan Cross Check Code. Kemudian pihak Pemerintah Indonesia melakukan kerja sama dengan Google dengan Cross Check dan Facebook dengan Fast Check-nya terkait praktik Hoax. Pihak Kementerian Komunikasi dan Informatika Republik Indonesia juga dapat melakukan pemblokiran terhadap situs-situs penyebar Hoax, fitnah. Lembaga Kepolisian Republik Indonesia dapat juga melakukan tindakan hukum. Tak kalah penting adanya komunitas Turn Back Hoax misalnya Forum Anti Hoax, Database, Sosialisasi. Forum anti fitnah, hasut dan Hoax misalnya publik melaporkan link, situs, berita yang dianggap perlu verifikasi. Melakukan dengan database dengan cara menyimpan dan mengurutkan laporan dari publik; data.tumbackhoax.id. Selanjutnya ada tim Cross Checker yang melakukan investigasi untuk mendapatkan kebenaran terhadap sebuah laporan, menjawab laporan dan pertanyaan di FB Group. Pihak institusi pendidikan misalnya memperbanyak referensi buku tentang literasi media di sekolah, Universitas, dapat melakukan penelitian Hoax Buster.

Selain itu juga dapat dilakukan langkah-langkah memerangi hoax dan fake news secara modern dengan t konten. Sedangkan cara tradisional dalam memerangi Hoax dan Fake News; Wartawan dapat melakukan investigasi dengan memanfaatkan geolokasi dan reverse image searches digunakan 
untuk menyimpan informasi dimana konten dibuat, dan akan terdeteksi siapa yang mengambil foto-foto yang sama, lokasi foto asli, terbitnya dimana. Sikap wartawan harus bisa membongkar hoax dan fake news dengan cara mengamplifikasi atau mematahkannya kepada publik. Wartawan harus transparan dengan mengoreksi terbuka dari editor, dan harus berusaha melakukan literasi media dengan tujuan mengedukasi audiens atau masyarakat.

Dapat disimpulkan bahwa banyak faktor yang menyuburkan berita Hoax dan Fake News. Pendekatan un verifikasi media massa, stempel Hoax, atau forum verifikasi saja tidak cukup. Perlu adanya situs Cross Check di Indonesia yaitu perlu dibuat agar mudah digunakan Hoax buster, kredibel, independen, dan bisa dipercaya semua pihak. Perlu lebih banyak Cross Checker yang menulis artikel hasil verifikasi. Ada beberapa solusi yang seyogianya dilakukan pemerintah dan masyarakat guna mengantisipasi efek negatif berita hoax ini. Pertama, bergabung dalam komunitas masyarakat anti hoax. Salah satunya yaitu komunitas Masyarakat Indonesia Anti Hoax. Kedua, mengecek lebih dulu akan kebenaran suatu berita (tabayyan). Seringkali masyarakat cenderung mudah dipermainkan arus informasi yang kontinyu dan masif di media sosial, situs dalam jaringan (daring) maupun media massa. Ketiga, blokir situs abal-abal atau akun media sosial penyebar berita hoax. Berbagai media sosial saat ini sudah memberikan fitur pelaporan jika ada berita yang tidak sesuai, salah satunya Twitter.

\section{DAFTAR PUSTAKA}

Abrar Nadhya Ana, 1997. Bila Fenomena Jurnalisme Direfleksikan. Jakarta: Pustaka Sinar Harapan.

Allan,Stuart, 2006. Online News, London: McGraw Hill.

Al-Qurthûbi, al-Jâmi ‘ liAhkâm al-Qur'ân, Dâr , juz XVI, hlm

Bajari, Atwar, dan Sahat Sahala Tua Sargih, 2011. Komunikasi Kontekstual. Teori dan Praktik Komunikasi Kontemporer, Bandung: PT. Remaja Rosdakarya.

Baran, J Stanley, 2012. Pengantar Komunikasi Massa, Melek Media dan Budaya. Jakarta: Erlangga. 
Branston, Gill dan Stafford, Roy, 1996. The Media Student's Book. London\&Newyork: Routledge Taylor\&Francis Group.

Briggs, Asa dan Burke, Peter, 2000. A Social History of the Media. New York: Cambridge-UK.

Christel, G.C. van de Burgt, 2008. Journalism Ethics in Perspective Desirability and Feasibility of a Separate Code of Conduct for Online Journalism. Amsterdam: The University of Amsterdam.

Chomsky, Noam, 2007. Chomsky Propaganda Model. University of Windsor: Canada.

Craig, Richard, 2005. Online Journalism: Reporting, Writing and Editing for New Media. Australia, Canada.

Creech, Kenneth C, 2007. Electronic Media Law and Regulation. Oxford: Focal Press.

Davis, Aeron, 2019. Political Communication; a New Introduction for Crisis Times. USA, Polity Press.

Fathurokhmah, Fita, 2010. Propaganda Media dalam Mewacanakan Komunitas Agama. Jakarta, Sedaun Press.

2017. Menghadapi Krisis Hoax di Media Sosial: Jurnalisme Online dalam Regulasi Media di Indonesia. Yogyakarta: ASKOPIS Press. ,2019. Komunikasi Komunitas Virtual dan Gaya Hidup Global Kaum Gay di Media Sosial. Jakarta: Jurnal Kajian Dakwah dan Kemasyarakatan UIN Syarif Hidayatullah Jakarta, Vol 23 No 1, 2019.

di Media Massa. Salatiga Jawa: INJECT Inyerdisciplinaru Journal of Communication IAIN Salatiga.

Feldmn, Tony, 1997. Introduction to Digital Media. London: Routledge.

Halliday J, Sherry and Coombs W Timothy, 2010. The Handbook of Crisis Communication. Singapore. 
Herman, S Edward and Chomsky, Noam, 2002. Manufacturing Consent: The Political Economy of the Mass Media. New York: Pantheon Books.

Jasmadi, 2008. Membangun Komunitas Online secara Praktis dan Gratis. Jakarta: Elex Media Computindo.

Kaplan, Anderas M dan Haenlein, Michael, 2010. User of the World. United The Challenges and The Opportunities of Social Media

Maryono,2008. Teknologi Informasi dan Komunikasi. Yogyakarta: Yudhistira Ghalia Indonesia.

McQuail, Dennis, 2011. Teori Komunikasi Massa, Jakarta: Salemba Humanika. , 2000. Mass Communication Theory, $4^{\text {th }}$ Edition. London: Thousand Oaks, New Ddelhi: Sage Publications.

Mia, Consalvo and Charles, Ess. 2011 The Handbook of Internet Studies. United Kingdom: Wiley-Blacwell.

Mitchell JT W and Hansen BN Mark, 2010 Critical Terms For Media Studies. Chicago and London: The University of Chicago Press.

Nasrullah, Rulli, 2014. Teori dan Riset Media Siber (Cybermedia). Jakarta: Kencana. ,2015, Media Sosial. Bandung: Simbiosa Rekatama Media

Piliang Amir Yasraf,2004. Posrealitas: Realitas Kebudayaan dalam Era Postmetafisika. Yogyakarta: Jalasutra.

Purwanto, Didik, 2012. Dominasi Pengguna Internet Mobile. http://tekno.kompas.com/read/2012/02/22/17525296/.

Quinn Stephen and Filak F Vincent, 2005. Convergent Journalism: an Introduction. Oxford: Focal Press.

Ramdan, Anton, 2013. Jurnalistik Islam, (Shahara Digital Publishing )

Zarella, Dan, The Sosial Media Marketing Book, 2010. Canada: O’Reilly Media. 
